\title{
FIDELITY CASE MANAGEMENT SYSTEM PADA PASIEN STROKE RAWAT INAP DI RUMAH SAKIT UNIVERSITAS GADJAH MADA
}

\author{
Novi Zain Alfajri ${ }^{1}$, Rizaldy Taslim Pinzon ${ }^{2}$, Trisasi Lestari ${ }^{3}$ \\ ${ }^{1}$ Magister Manajemen Rumah Sakit Fakultas Kedokteran Universitas Gadjah \\ Mada \\ ${ }^{2}$ Fakultas Kedokteran Universitas Kristen Duta Wacana \\ 3Program Studi Ilmu Kesehatan Masyarakat Fakultas Kedokteran Universitas \\ Gadjah Mada
}

Korespondensi: novizainalfajri@gmail.com

\begin{abstract}
ABSTRAK
Latar Belakang: Koordinasi asuhan pasien masih bermasalah di RS UGM khususnya dalam perencanaan perawatan dan proses transisi. RS UGM menerapkan case management system untuk memperbaiki koordinasi asuhan kasus kompleks salah satunya stroke. Evaluasi dilakukan terhadap implementasi sistem tersebut.

Tujuan: Mengevaluasi fidelity case management pasien stroke rawat inap dan mengidentifikasi faktor-faktor implementasinya.

Metode: Penelitian implementasi, disain concurrent mixed method, dilaksanakan November 2016-Januari 2017 di RS UGM. Pengambilan data dengan wawancara mendalam terhadap case manager, diskusi kelompok terarah paramedis, dan observasi proses koordinasi. Fidelity yang dinilai meliputi kepatuhan terhadap cakupan dan konten. Evaluasi luaran dibatasi pada lama hari rawat dan angka kematian.

Hasil dan Pembahasan: Kepatuhan alur case management dan cakupan kasus masih rendah yaitu $2 \%$ dan 19\%. Ketersediaan petunjuk teknis dan pemahaman professional pemberi asuhan yang belum memadai menjelaskan rendahnya kepatuhan dan rendahnya cakupan kasus. Faktor pendukung implementasi adalah ketersediaan panduan, pelatihan, dukungan pimpinan, dan respon tim. Kendala implementasi adalah kurangnya petunjuk teknis, kendala waktu koordinasi akibat terbatasnya SDM, dan tingkat sosial edukasi pasien. Evaluasi angka kematian menurun, rerata lama hari rawat memanjang. Responden merasakan manfaat case management dalam memperbaiki koordinasi tim.

Kesimpulan: Fidelity implementasi case management system di RS UGM rendah dalam hal kepatuhan konten dan cakupan kasus. Rerata lama hari rawat memanjang, tetapi rentang hari rawat memendek. Angka kematian kasus yang dengan case management system lebih kecil. Respon partisipan mendukung implementasi. Strategi fasilitasi belum optimal sehingga mempengaruhi rendahnya fidelity.
\end{abstract}

Kata Kunci: fidelity, stroke, case management system 


\title{
FIDELITY OF CASE MANAGEMENT SYSTEM FOR STROKE PATIENT AT UNIVERSITAS GADJAH MADA HOSPITAL
}

\author{
Novi Zain Alfajri ${ }^{1}$ Rizaldy Taslim Pinzon ${ }^{2}$ Trisasi Lestari ${ }^{3}$ \\ ${ }^{1}$ Magister Manajemen Rumah Sakit Fakultas Kedokteran Universitas Gadjah \\ Mada \\ ${ }^{2}$ Fakultas Kedokteran Universitas Kristen Duta Wacana \\ ${ }^{3}$ Program Studi Ilmu Kesehatan Masyarakat Fakultas Kedokteran Universitas \\ Gadjah Mada \\ Correspondence: novizainalfajri@gmail.com
}

\begin{abstract}
Background: Care coordination is still problematic in UGM Hospital especially in care planning and transition process. UGM Hospital implementing case management systems to improve care coordination for complex cases include stroke patient. An evaluation of the system is required

Objective: To evaluate the fidelity case management of stroke patients hospitalized and identify the implementation related factors.

Methods: The study implementation, concurrent design mixed method, carried out in November 2016-January 2017 in UGM Hospital. Retrieving data used are in-depth interview, focus group discussions, and observation of the coordination process. Fidelity assessed include adherence to the scope and content. Evaluation of outcomes is limited to the average length of stay and mortality rate.

Results and Discussion: Adherence to the content of case management is only $2 \%$. The screening and post discharge follow up steps have not been fulfilled because of the implementer's adherence and competence and the lack of technical guidelines. The discrepancy of screening affects the low coverage of cases i.e. 19\%. The supporting factors of implementation are participant responsiveness, and the barriers of implementation include low facilitation strategies such as lack of technical manuals and training. Outcomes evaluation showed declining mortality, increased average length of stay. Respondents gain the benefit of case management in improving care coordination among providers.

Conclusions and Recommendations: The low fidelity of case management system at UGM Hospital indicated by low adherence of content and coverage. The average length of stay is lengthened, but the day range is shortened. Stroke case mortality rate with case management is smaller. Good participant's responsiveness as a moderator factor of fidelity but incomplete facilitation strategy can be an explanation for the low fidelity.
\end{abstract}

Keywords: fidelity, stroke, case management system 


\section{PENDAHULUAN}

Mutu pelayanan dan koordinasi asuhan masih menjadi permasalahan di Rumah Sakit Universitas Gadjah Mada (RS UGM). Ketidakjelasan transisi/ handover pasien, perencanaan perawatan/ terapi, dan realisasi rencana terapi merugikan pasien dan menyebabkan ketidaknyamanan hubungan antar petugas/ unit pada kasus kompleks yang salah satunya adalah stroke. Implementasi case management untuk kasus stroke di RS UGM diharapkan mampu meningkatkan koordinasi asuhan, menambah nilai bagi pasien dan keluarga, mengurangi dampak yang serius pasca rawat, dan secara umum meningkatkan mutu pelayanan. Kajian awal diperlukan untuk evaluasi implementasi case management di RS UGM untuk memastikan implementasi yang optimal.

Stroke merupakan salah satu penyakit kronis yang kompleks dan berdampak besar terhadap kondisi fisik pasien serta kehidupan sosial dan ekonominya. Bahkan kasus stroke merupakan salah satu penyakit yang berisiko tinggi menyebabkan kematian. Manajemen penyakit stroke ketika terjadi serangan, selama perawatan, hingga manajemen pasca stroke membutuhkan intervensi yang komprehensif untuk pengendalian faktor risiko, pemenuhan terapi dan rehabilitasi, serta pencegahan readmisi dan rekurensi stroke. ${ }^{1,2}$

Case Management adalah proses kolaborasi dalam hal asesmen, perencanaan, fasilitasi, koordinasi asuhan, evaluasi, dan advokasi pilihan pelayanan untuk memenuhi kebutuhan yang komprehensif dari pasien dan keluarga melalui komunikasi, dan tersedianya sumber daya yang memadai untuk mencapai luaran yang efektif. ${ }^{3}$ Ruang lingkup pelayanan case management meliputi edukasi, koordinasi asuhan, pemenuhan kebutuhan pasien, manajemen transisi, dan manajemen utilisasi. ${ }^{4}$ Case Management diyakini efektif dalam meningkatkan luaran pasien stroke, mengurangi risiko kecacatan, mengurangi restriksi partisipasi peran, memperbaiki persepsi kesehatan, mengurangi biaya perawatan, mengurangi lama rawat, mengurangi readmisi, mengurangi hospitalisasi tak terencana, menambah nilai, kepuasan, kemandirian pasien dan kualitas hidup yang lebih baik.5,6

Penting untuk menilai fidelity case management karena variabel ini menjembatani hubungan antara intervensi case management dengan luarannya dan mencegah kesimpulan yang salah tentang efektivitas sistem ${ }^{7}$. Terdapat 5 elemen dalam fidelity yaitu kepatuhan yang terdiri atas content, cakupan, dose delivery; paparan yang berkaitan dengan jumlah program yang dilaksanakan, jumlah kehadiran, jumlah dan durasi sesi; mutu intervensi; respon partisipan; dan diferensiasi program. 7,8 Selain itu terdapat elemen moderator potensial yang mempengaruhi kepatuhan yaitu kompleksitas intervensi, strategi fasilitasi, mutu intervensi, deskripsi kebijakan yang komprehensif, respon partisipan, rekruitmen dan konteks layanan. ${ }^{8}$

\section{METODE PENELITIAN}

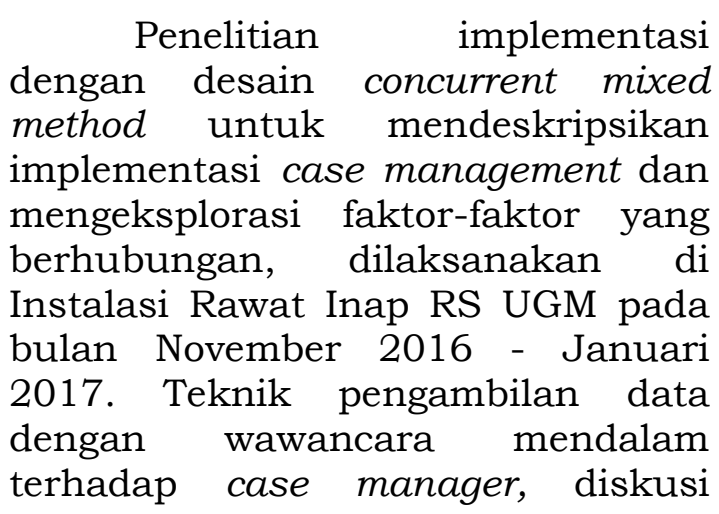


kelompok terarah pada 6 orang paramedis dengan purposive sampling, serta $4 \mathrm{x}$ observasi proses koordinasi asuhan pasien stroke dengan convenience sampling. Variabel yang dinilai adalah fidelity yang meliputi kepatuhan terhadap konten dan cakupan case management, lama hari rawat dan angka kematian kasus strokes sebagai luaran pasien, serta deskripsi moderator potensial yaitu strategi fasilitasi dan respon partisipan. Variabel karakteristik pasien dideskripsikan untuk memperkaya analisis data. Analisis data kuantitatif univariate untuk mendeskripsikan karakteristik kasus dan luaran pasien. Analisis data kualitatif untuk menjelaskan faktorfaktor yang berhubungan dengan implementasi case management. Konfirmasi data dilakukan dengan telaah data rekam medis, dokumen kebijakan, clinical pathway, dan dokumentasi kegiatan case manager.

\section{HASIL PENELITIAN}

Karakteristik pasien stroke RS UGM sejak penerapan case management system tahun 2016 pada Tabel 1 .

Tabel 1. Karakteristik pasien stroke tahun 2016

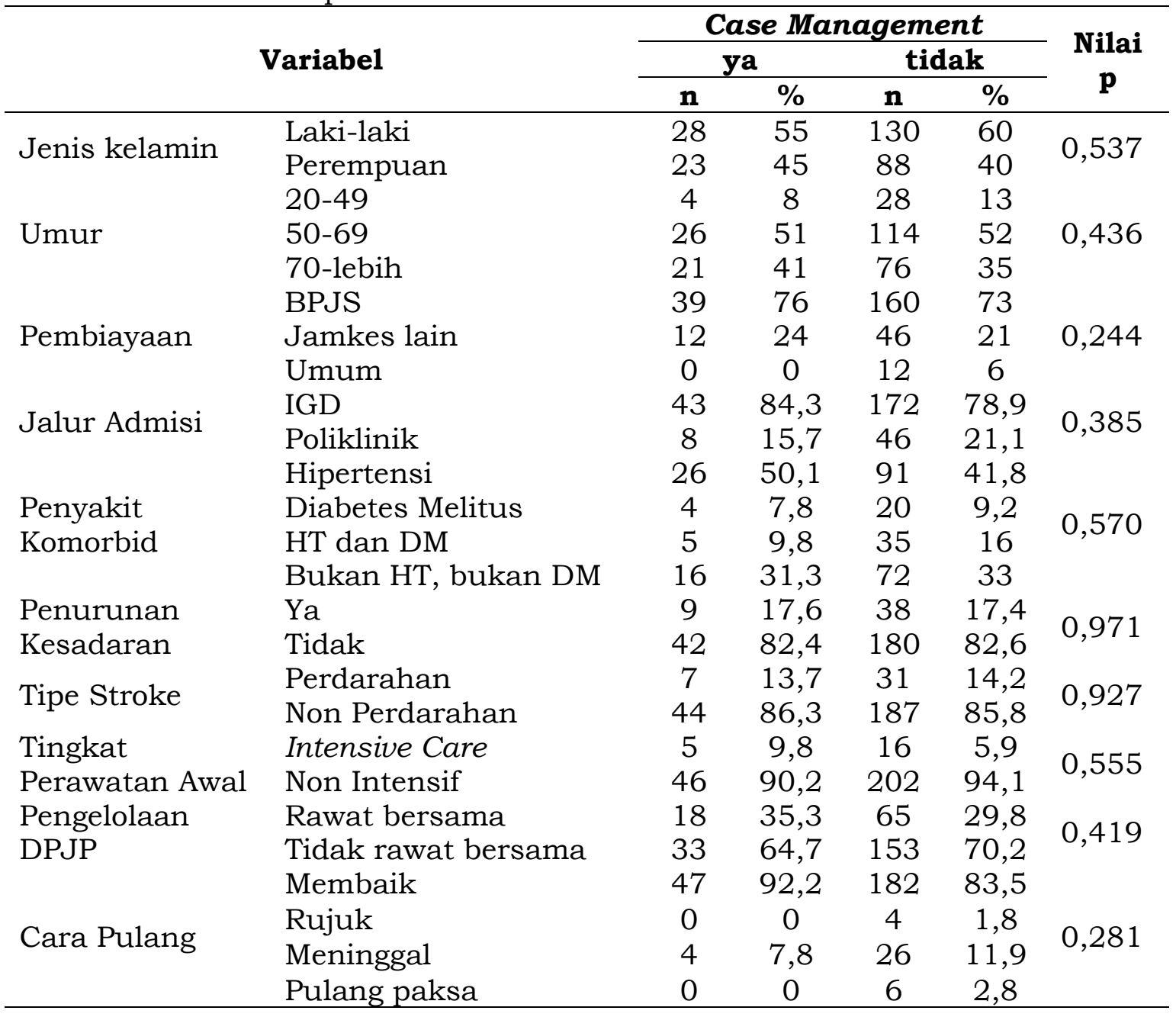

Karakteristik pasien case management dibandingkan dengan pasien tanpa case management tidak menunjukkan perbedaan yang signifikan (tabel 1). 
Kesesuaian pelaksanaan case management system

Evaluasi standar proses difokuskan pada kepatuhan dalam hal konten alur dan ruang lingkup, serta cakupan case management system. Evaluasi ouput dilakukan untuk capaian lama hari rawat dan angka kematian kasus.

a. Kepatuhan terhadap konten/ alur case management system

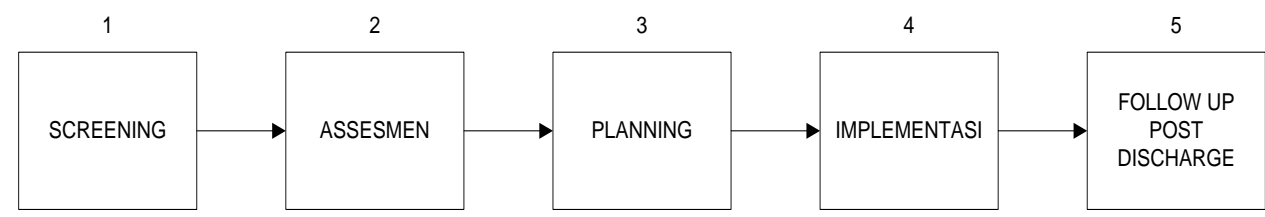

Gambar 1. Alur Case Management RS UGM

Diadopsi dan disesuaikan dari Comission for Case Manager Certification, 2011

Komponen esensial dalam panduan case management meliputi skrining, asesmen, planning, implementasi, dan follow up post discharge (alur case management).

\section{Skrining}

Skrining merupakan langkah awal dari case management. Pada tahap ini, terdapat modifikasi subproses menjadi Skrining Aktivasi, Aktivasi Case Manager, dan Skrining Verifikasi. Skrining Aktivasi dilakukan oleh dokter/ perawat jaga sesuai kriteria kasus yang perlu case management yaitu kasus risiko tinggi, high cost, multi-diagnosis / multi-dokter penanggung jawab pelayanan (DPJP), risiko length of stay panjang, faktor psikososial, faktor ekonomi, atau faktor lain yang berisiko menjadi masalah dalam pelayanan. Apabila ditemukan minimal 1 kriteria maka perawat/dokter akan melakukan Aktivasi Case Manager. Case manager merespon aktivasi tersebut dengan melakukan Skrining Verifikasi kriteria kasus kemudian mengidentifikasi kebutuhan pasien tersebut.

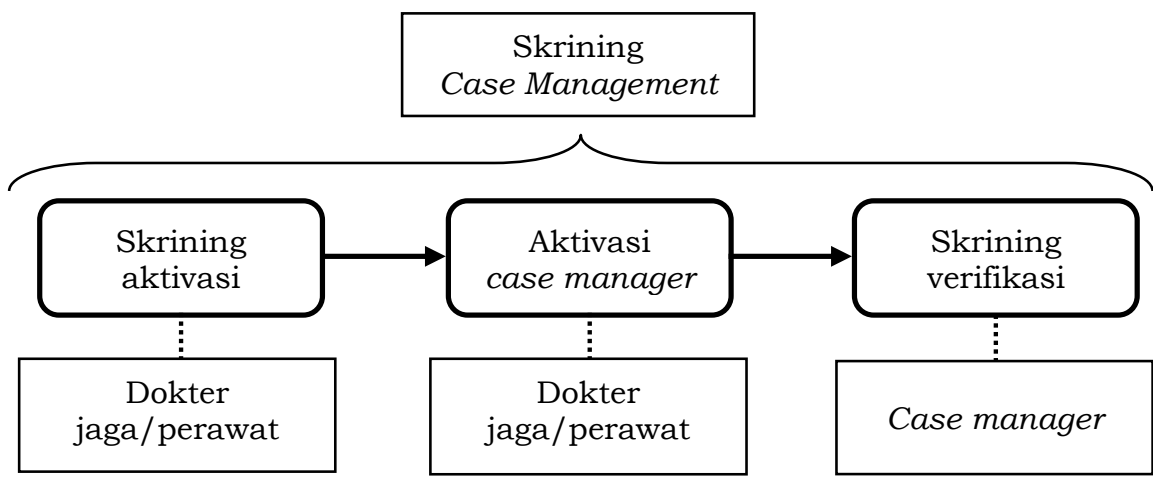

Gambar 2. Modifikasi proses skrining

Modifikasi tahap skrining tersebut merupakan kesepakatan bersama dengan tim pemberi asuhan untuk mengatasi keterbatasan jumlah case manager. Telusur data dari 51 pasien yang didampingi case manager pada tahun 2016, menunjukkan sebagian besar kriteria yang diidentifikasi adalah 
"multi diagnosis/ multi DPJP" yaitu sebesar $51 \%$ kasus. Tidak ditemukan kasus dengan kriteria "faktor ekonomi" pada Skrining Aktivasi. Ditemukan kriteria "risiko lain" pada 1 kasus yaitu kondisi keluarga pasien dengan kecemasan dan banyak keluhan selama pelayanan yang dapat menghambat proses pelayanan.

\section{Asesmen}

Asesmen yang dilakukan oleh case manager secara langsung atau melalui koordinasi tim pemberi asuhan sehingga didapatkan hasil asesmen yang lebih komprehensif meliputi aspek klinis dan non klinis yang dirumuskan sebagai asesmen kebutuhan pasien.

\section{Planning}

Hasil asesmen pasien dirumuskan sebagai rencana tindak lanjut perawatan (care plan) yang mencakup aspek klinis maupun administratif. Case manager memfasilitasi kolaborasi tim klinis maupun administratif dalam penyusunan care plan tersebut.

\section{Implementasi}

Komponen ini merupakan proses untuk memenuhi rencana asuhan yang telah disusun oleh tim. Case Manager melakukan monitoring implementasi care plan dari masing-masing profesi yang merawat pasien. Bukti kegiatan implementasi care plan didokumentasikan dalam bentuk asesmen ulang dan perencanaan ulang dalam konteks evaluasi pasien secara periodik sesuai kebutuhan selama pasien dirawat.

\section{Follow up post discharge}

Pasien diidentifikasi kebutuhan pemulangannya untuk disiapkan kebutuhan tersebut sedini mungkin, dilakukan edukasi, untuk memastikan pasien tetap terpenuhi kebutuhannya setelah pulang dari rumah sakit. Dalam 2x24 jam pasca pemulangan, case manager akan melakukan tindak lanjut dengan metode telepon atau kunjungan rumah.

Case manager harus mendokumentasikan setiap kegiatan sesuai alur dalam sistem informasi elektronik untuk memberikan deskripsi bukti kegiatan pada setiap alur proses mulai dari skrining hingga follow up post discharge. Akan tetapi hasil telaah menunjukkan kegiatan alur case management tidak terdokumentasi dengan lengkap.

Tabel 2. Kepatuhan dokumentasi alur Case Management ( $\mathrm{n}=45$ kasus)

\begin{tabular}{lcc}
\hline \multirow{2}{*}{ Kegiatan/Alur case management } & n & Kepatuhan \\
\cline { 2 - 3 } & 45 & 100 \\
Aktivasi case manager & 18 & 40 \\
Skrining (verifikasi) & 12 & 27 \\
Asesmen & 24 & 53 \\
Planning & 30 & 67 \\
Implementasi & 1 & 2 \\
Follow up post discharge & 1 & 2 \\
Seluruh alur lengkap &
\end{tabular}

Hasil diskusi kelompok terarah menguatkan temuan masalah dalam hal kepatuhan dokumentasi tersebut. “,...kadang asessmen itu baru dilengkapi di akhir... saya juga tidak yakin apakah DPJP benar - benar membaca itu ..."

(dietisian) 
b. Kepatuhan konten ruang lingkup case management RS UGM

Ruang lingkup case management meliputi edukasi, care coordination, manajemen transisi, manajemen utilisasi.

\section{Edukasi}

Case Manager melakukan koordinasi dengan tim pemberi asuhan dalam hal edukasi kepada pasien. Peran case manager adalah mengkoordinasikan kebutuhan edukasi dan pelaksanaannya. Case manager melakukan edukasi aspek administratif pelayanan dan proses pelayanan yang bersifat umum. Edukasi aspek klinis dilakukan oleh profesional pemberi asuhan.

\section{Koordinasi Asuhan}

Koordinasi asuhan difokuskan pada penyamaan persepsi, data/ information sharing, konfirmasi terkait rencana perawatan pasien, pengobatan, dan pengendalian risiko dalam pelayanan. Case Manager memfasilitasi koordinasi tim melalui metode komunikasi interpersonal dengan profesional pemberi asuhan yang diberi istilah Single Provider Coordination (SgPC), program Visite Bersama tim pemberi asuhan, atau Interprofesional Team Meeting (ITeM) yaitu suatu bentuk diskusi kasus dengan tim yang melibatkan manajemen RS UGM. Case manager juga memfasilitasi koordinasi berbasis teknologi informasi dan aplikasi media sosial "whatsapp" yang diberi istilah Online Interprofessional Communication (OnIC). Hasil observasi pada 4 kasus menunjukkan aktivitas case manager dalam koordinasi asuhan. Case manager berperan sebagai moderator diskusi, melakukan pemantauan tatalaksana pasien dan memberikan umpan balik kepada tim (koordinasi intra hospital). Koordinasi dengan pasien dan keluarga dilakukan untuk mengoptimalkan luaran dan mendorong kemandirian pasien dan keluarga. Belum tampak pembahasan koordinasi dengan fasilitas kesehatan lain yang diperlukan pasien pasca dirawat (koordinasi ekstra hospital).

\section{Manajemen Transisi}

Transisi pasien intra hospital dimonitor oleh case manager dalam hal kesesuaian alur dan kebutuhan transfer. Manajemen transisi ekstra hospital dimulai dengan discharge planning, penyiapan pasien dan keluarga yang akan merawat, dilanjutkan kegiatan follow up post discharge untuk memastikan transisi pasien berjalan baik.

\section{Manajemen Utilisasi}

Sumber daya pelayanan dikendalikan dengan cara verifikasi kelas perawatan, penentuan pemeriksaan penunjang dan penggunaan obat serta sumber daya lain, pemantauan dan umpan balik tentang billing pasien kepada tim pemberi asuhan. Case manager mendorong tim dalam pemanfaatan sumber daya secara efisien tanpa mengorbankan aspek mutu lainnya meskipun terkadang cukup dilematis.

c. Kepatuhan terhadap cakupan case management system

Cakupan case management adalah proporsi kasus yang didampingi case manager pada tahun 2016 yang menunjukkan kemampuan case management dalam merespon kebutuhan pasien. Cakupan menjadi salah satu indikator kesesuaian/ fidelity implementasi. Cakupan case management tahun 2016 ditunjukkan pada tabel berikut: 
Tabel 3. Cakupan Case Management pasien Stroke $2016(n=269)$

\begin{tabular}{lcc}
\hline Kategori & Jumlah & \% \\
\hline Jumlah Aktivasi Case Manager & 51 & 19 \\
Pendampingan Case Manager & 51 & 19 \\
\hline
\end{tabular}

Dilihat dari cakupan case management stroke dibanding total kasus stroke hanyalah $19 \%$. Hal ini menimbulkan kecurigaan adanya masalah dalam hal skrining pasien stroke yang perlu case management sehingga cakupannya masih rendah.

\section{Evaluasi lama hari rawat dan angka kematian kasus}

a. Lama Hari Rawat pasien stroke tahun 2016

Tabel 4. Lama Hari Rawat Pasien Stroke sebelum dan setelah case management

\begin{tabular}{lcc}
\hline \multicolumn{1}{c}{ Kategori } & $\begin{array}{c}\text { sebelum } \\
\text { implementasi (tahun } \\
\text { 2015) }\end{array}$ & $\begin{array}{c}\text { setelah } \\
\text { implementasi (tahun } \\
\text { 2106) }\end{array}$ \\
\hline Jumlah kasus (n) & 132 & 227 \\
Total lama hari rawat & 688 & 1207 \\
Rerata lama hari rawat & 5,21 & 5,7 \\
Lama hari rawat maksimal & 20 & 18 \\
Lama hari rawat minimal & 1 & 2 \\
\hline
\end{tabular}

Rerata lama hari rawat pasien stroke periode 2016 adalah 5,7 hari, lebih panjang jika dibandingkan tahun 2015 yaitu 5,21. Lama rawat maksimal menurun dari 20 hari di tahun 2015 menjadi 18 hari di 2016. Lama hari rawat minimal tahun 2016 adalah 2 hari. Dapat dikatakan rentang lama rawat pasien stroke setelah implementasi case management system menjadi lebih pendek.

Beberapa kasus stroke disertai kondisi ketidakseimbangan elektrolit, pneumonia, gagal jantung, atau penyakit katastropik lain sehingga perawatan pasien menjadi lebih lama kemungkinan akibat penyakit penyertanya. Beragam-
Lama hari rawat merupakan salah satu indikator kinerja/ mutu pelayanan. Data penelitian menunjukkan variabel lama hari rawat pasien stroke tahun sebelum dan setelah implementasi case management system adalah sebagai berikut: 
Tabel 5. Angka kematian pasien stroke tahun 2016

\begin{tabular}{lcc}
\hline & $\begin{array}{c}\text { Sebelum implementasi } \\
\text { (tahun 2015) }\end{array}$ & $\begin{array}{c}\text { Setelah implementasi } \\
\text { (tahun 2016) }\end{array}$ \\
\hline Jumlah Kasus (n) & 172 & 269 \\
Jumlah Kematian & 27 & 30 \\
Angka kematian & $16 \%$ & $11 \%$ \\
\hline
\end{tabular}

Faktor Moderator pada fidelity implementasi case management

a. Strategi fasilitasi implementasi case management system

Strategi fasilitasi dimaksud adalah penyediaan sumber daya untuk optimalnya implementasi sesuai rancangannya antara lain penyediaan panduan dan petunjuk teknis yang memadai, pemenuhan kebutuhan SDM case manager termasuk tatakelola, kebutuhan pelatihan dan sistem insentif case manager, serta sistem teknologi informasi yang mendukung pelaksanaan sistem. Dukungan sistem teknologi informasi untuk dokumentasi kegiatan case management terintegrasi dalam electronic health records pasien.

Pemenuhan standar sumber daya manusia dalam panduan case management system mengatur tentang standar kualifikasi dan kompetensi case manager yaitu dokter umum atau ners dengan pengalaman klinis minimal 3 tahun, memiliki pemahaman tentang standar pelayanan, kebijakan Jaminan Kesehatan Nasional (JKN), menguasai keterampilan komunikasi interpersonal, komunikasi efektif, dan teknik konseling sederhana. ${ }^{9}$ Pengelolaan kasus stroke dilakukan oleh salah satu case manager yaitu ners, dengan pengalaman klinis yang dimiliki selama 10 tahun sebagai perawat fungsional. Pemenuhan kompetensi dasar dilakukan melalui pelatihan internal untuk case manager, dokter, dan perawat penanggung jawab ruang rawat.

"case manager ini misalnya diikutkan kursus dimana begitu..mungkin magang di rumah sakit mana yang betul - betul menggambarkan ini loh case management .. saya kira itu akan membuat kami menjadi lebih confident."

(case manager)

Telaah dokumen kebijakan menemukan kelemahan strategi fasilitasi dalam kebijakan jenjang karir jabatan dan sistem insentif case manager dalam tata kelola sumber daya manusia di RS UGM. Fasilitasi dalam penyediaan anggaran juga belum tercantum secara jelas dalam rencana anggaran tahunan RS UGM.

b. Respon partisipan terhadap case management

Partisipan dalam sistem case management pihak yang terlibat yaitu case manager, profesional pemberi asuhan, serta pasien dan keluarga. Case manager memiliki persepsi dan keyakinan tentang keunggulan dan manfaat sistem case management. Komitmen case manager terlihat dari semangat mereka untuk melakukan koordinasi asuhan meskipun belum ada jenjang karir dan insentif yang jelas. Hasil diskusi kelompok terarah, respon PPA bermacam-macam di awal implementasi. Case Manager dipandang hanya sebagai mekanisme menekan 
biaya perawatan untuk

(perawat 2)

mengendalikan klaim.

"Masih ada yang beranggapan bahwa case manager ini e.. apa.. ngurusin plafon.. plafon - plafon terkait dengan klaim BPJS itu."

(case manager)

Pada tahap selanjutnya, secara umum penerimaan PPA terhadap sistem dan case manager cukup baik. Demikian juga penerimaan pasien dan keluarga. Dokter penanggung jawab pelayanan bahkan melibatkan case manager dalam pengambilan keputusan untuk pasiennya.

"case manager itu memang membantu, sehingga kami dicari begitu.."

"pasien dan keluarga sepertinya sangat nyaman dengan adanya kami karena mereka merasa terfasilitasi”

(case manager)

\section{Hambatan implementasi case management system}

Beberapa hambatan yang diidentifikasi adalah kurangnya jumlah case manager, apoteker, dietisien, fisioterapis, serta adanya hambatan komunikasi antara dokter dengan paramedis.

“...yang paling sulit bila beberapa DPJP berbeda pendapat sehingga butuh tambahan waktu untuk pelayanan pasien untuk confirm."

Tabel 6. Identifikasi hambatan implementasi pada level pemangku kepentingan

\begin{tabular}{|c|c|}
\hline Kategori & Hambatan \\
\hline $\begin{array}{l}\text { Level } \\
\text { pasien }\end{array}$ & $\begin{array}{l}\text { Hambatan komunikasi karena usia dan literasi kesehatan yang } \\
\text { berhubungan dengan tingkat sosial pendidikan } \\
\text { Kompleksitas kebutuhan dan permasalahan masing-masing pasien } \\
\text { sangat bervariasi }\end{array}$ \\
\hline $\begin{array}{l}\text { Level } \\
\text { provider }\end{array}$ & $\begin{array}{l}\text { Perbedaan persepsi tentang tujuan dan ruang lingkup case } \\
\text { management serta tugas dan wewenang case manager } \\
\text { Persepsi kurang waktu dan kurang SDM untuk koordinasi tim dan } \\
\text { melaksanakan standar asuhan yang ideal }\end{array}$ \\
\hline $\begin{array}{l}\text { Level } \\
\text { organisasi }\end{array}$ & $\begin{array}{l}\text { Dukungan kebijakan dan desain sistem yang belum lengkap } \\
\text { Belum ada kebijakan yang kuat mengenai jabatan case manager } \\
\text { Belum jelasnya sistem insentif bagi case manager }\end{array}$ \\
\hline
\end{tabular}




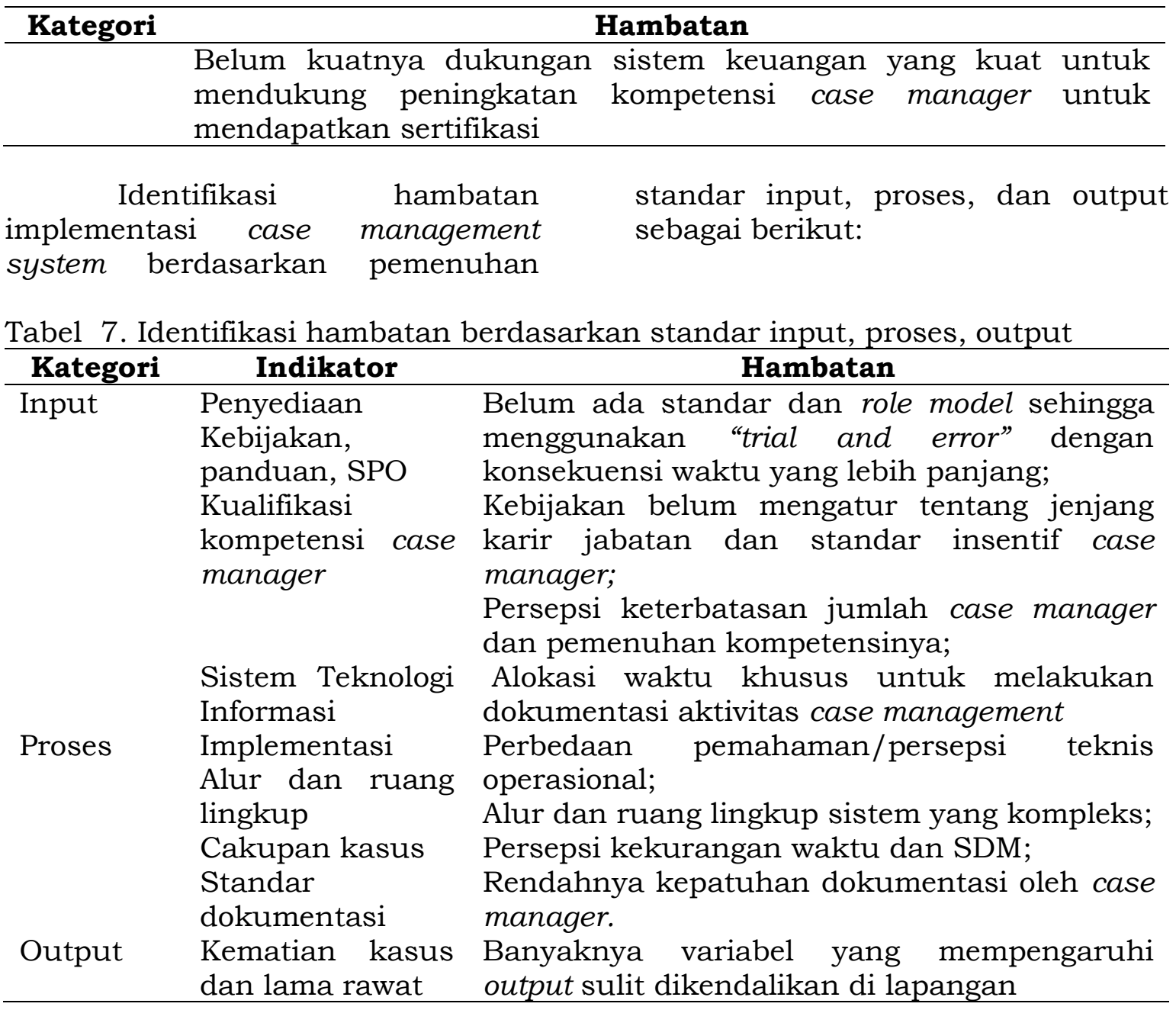

\section{PEMBAHASAN}

Elemen kepatuhan di dalam pengukuran fidelity sesuai Conceptual Framework for Implementation Fidelity meliputi variabel konten, cakupan, frekuensi paparan, dan durasi. ${ }^{7}$ Penelitian ini hanya mengukur konten dan cakupan saja oleh karena frekuensi dan durasi intervensi dilakukan kontinyu selama pasien dirawat. Kepatuhan konten difokuskan pada alur dan ruang lingkup case management tetapi hanya $2 \%$ kasus yang terdokumentasi mendapatkan komponen alur dengan lengkap. Masing-masing komponen alur merupakan sebuah rantai proses yang berkesinambungan dan menggambarkan kontinuitas pelayanan pasien stroke.

Pendokumentasian proses sangat diperlukan untuk menilai kontinuitas pelayanan tersebut dan mengidentifikasi kekurangan dalam sub prosesnya. Perlu kajian lebih lanjut mengenai penyebab rendahnya kepatuhan dokumentasi oleh case manager. Kebingungan case manager dalam kriteria kasus yang perlu dilakukan kunjungan rumah atau kontak telepon pasca rawat tampaknya menjadi penjelasan tidak sesuainya konten. Masalah pembiayaan terhadap telepon dan kunjungan rumah yang menjadi beban finansial rumah sakit memerlukan strategi yang matang. 
Karakteristik kasus dengan intervensi case management tidak berbeda secara signifikan dengan kelompok yang tidak dilakukan intervensi case management. Hal ini tidak mendukung konsep kasus stroke dalam case management system merupakan kasus yang lebih kompleks. Kemungkinan lain adalah kompleksitas kasus yang dikelola terletak pada variabel lain yang tidak diteliti dalam penelitian ini. Kriteria yang ditetapkan sebagai acuan skrining belum terdefinisikan secara operasional sehingga terjadi multi interpretasi kompleksitas kasus. Masalah dalam proses skrining dapat menjelaskan rendahnya cakupan. Dalam penelitian lain mengenai fidelity dari case management, kepatuhan juga menjadi masalah dalam hal rekrutmen kasus yang memenuhi kriteria inklusi, kesediaan untuk partisipasi sebagai responden, serta proses yang dirasakan cukup memakan waktu. ${ }^{10}$

Proses skrining yang dibebankan kepada dokter jaga dan perawat, merupakan tambahan tugas yang membutuhkan kompetensi dan alokasi waktu sehingga proses skrining sangat bergantung pada kepatuhan dan kompetensi dokter jaga dan perawat. Adanya multi interpretasi terhadap kriteria inklusi kasus dapat juga menjadi masalah. Perlu kriteria praktis yang mudah dipahami pelaksana skrining. Dalam bukunya berjudul The Case Manager's Handbook, Mullahy dkk merekomendasikan daftar "redflag" untuk case management yang berisi daftar kasus yang membutuhkan case management berdasarkan diagnosis penyakit, jenis perawatan, frekuensi hospitalisasi, pola perawatan, masalah saat hospitalisasi, masalah pasca hospitalisasi, kendala lokasi/ geografis, dan masalah farmasi." Daftar "redflag" semacam itu dapat memudahkan skrining kasus di lapangan.
Penelitian ini belum dapat menunjukkan efektivitas case management dalam menurunkan angka kematian kasus dan lama hari rawat. Angka kematian kasus stroke tahun 2016 lebih kecil (11\%) dibanding tahun 2015 (16\%) dan angka kematian stroke nasional $(14,5 \%) .{ }^{12}$ Rerata lama hari rawat pasien stroke 2016 memanjang tetapi rentang lama rawat memendek. Jika dibandingkan dengan standar ideal lama hari rawat yaitu 6-9 hari, atau dibandingkan dengan standar lama rawat dalam clinical pathway, maka rerata lama hari rawat pasien stroke RS UGM masih ideal.13 Tantangan selanjutnya adalah menurunkan variasi dan rentang lama hari rawat.

Penelitian-penelitian terdahulu menunjukkan manfaat case management dalam memperbaiki outcome klinis pasien antara lain menurunkan length of stay, mengurangi readmisi, mengurangi biaya, mengurangi kunjungan emergency, memperbaiki monitoring pasien, mengendalikan gejala/ keluhan, meningkatkan kepuasan pasien dan keluarga.14,15,16 Systematic review pada case management kasus cancer yang menelaah 7 paper yang memenuhi kriteria inklusi dari 654 yang diidentifikasi, mengemukakan bahwa hasil review tidak dapat menarik kesimpulan tentang pengaruh case management pada pasien cancer. Beragamnya instrumen dan metode asesmen yang digunakan menyebabkan studi tidak adekuat. Case management merupakan intervensi yang kompleks sehingga reproduksibilitasnya sulit. Ini disebut sebagai "black box" yang perlu diminimalkan dengan penyediaan petunjuk pelaksanaan yang lebih komprehensif, instrumen, dan akun aktivitas yang menggambarkan fidelity-nya. ${ }^{17,18}$

Faktor-faktor yang penting sebagai moderator kepatuhan antara 
lain respon partisipan, deskripsi kebijakan yang komprehensif, kompleksitas intervensi, strategi fasilitasi, rekrutmen, dan konteks implementasi. ${ }^{7}$ Kompleksitas case management ditandai dengan sekuensial sub proses yang panjang, banyaknya alternatif pilihan pengambilan keputusan pada setiap proses, serta banyaknya unit dan profesi yang terlibat. ${ }^{19}$ Semakin kompleks sebuah intervensi hambatan substansialnya semakin besar. $^{7}$ Strategi fasilitasi penting untuk mengurangi hambatan substansial antara lain dengan penyediaan panduan pelaksanaan dan standar prosedur operasional, penyelenggaraan pelatihan internal untuk case manager dan staf lain yang terlibat dalam sistem, penyediaan fasilitas yang mendukung tugas, dan komitmen untuk mencantumkan case manager dalam hospital by laws. Pemenuhan kompetensi case manager dengan pelatihan internal telah dilakukan tetapi diperlukan pelatihan tersertifikasi untuk pencapaian kompetensi case manager yang lebih terstandar mengingat kompetensi case manager mempengaruhi fidelity dan efektivitas case management dalam meningkatkan luaran pasien. ${ }^{7}$ Moderator potensial lainnya adalah respon partisipan. ${ }^{7,8,10}$ Respon yang dimaksud adalah bagaimana para pemangku kepentingan yaitu profesional pemberi asuhan, unit/staf lain yang terlibat, serta pasien dan keluarga merespon adanya case management. Secara umum pemangku kepentingan di RS UGM memiliki pemahaman yang baik dan berkontribusi positif terhadap case management. Kelemahan sistem case management di RS UGM adalah kurang detilnya panduan teknis, sehingga implementasi dan luarannya belum sesuai harapan. Hambatan di level provider telah berkurang dengan terbangunnya persamaan persepsi dan kenyamanan koordinasi dengan model case management. Tim pemberi asuhan menunjukkan keterbukaan dan partisipasi yang lebih baik. Hambatan di level pasien dan keluarga berupa kesenjangan pemahaman kesehatan diatasi dengan mengoptimalkan koordinasi, informasi, edukasi kepada pasien dan keluarga. Hambatan implementasi lainnya adalah persepsi keterbatasan jumlah dan kompetensi SDM, serta belum jelasnya kebijakan mengenai jenjang karir dan insentif case manager.

Hambatan implementasi case management dapat ditemukan di level organisasi, level provider, dan level pasien. Hambatan di level organisasi dapat berupa kurangnya dukungan pimpinan, kurangnya panduan teknis/ kebijakan, dan kurangnya sumber daya. Hambatan di level provider dapat berupa keengganan karena implementasi dianggap memakan waktu, ketidaknyamanan terhadap sistem baru, keengganan berubah, atau kurangnya keyakinan terhadap manfaat. Hambatan di level pasien dapat berupa kesulitan mempertahankan gaya hidup dan pengendalian faktor risiko. ${ }^{16}$ Hambatan dalam pencapaian luaran pasien dipengaruhi juga oleh banyaknya variabel karakteristik kasus dan variabel lain yang dapat mempengaruhi luaran pasien, yang pada penelitian ini tidak dikendalikan. 7,8

\section{KESIMPULAN}

Pelaksanaan case management system di RS UGM belum sesuai dengan panduan ditunjukkan dengan rendahnya kepatuhan konten alur case management dan cakupan kasus. Setelah implementasi case management system, rerata lama hari rawat pasien stroke memanjang akan tetapi rentang hari rawat memendek 
dan angka kematian kasus stroke lebih rendah. Faktor moderator potensial berupa respon partisipan mendorong fidelity implementasi case management system di RS UGM, tetapi strategi fasilitasi belum optimal sehingga implementasi case management belum memenuhi fidelity.

\section{DAFTAR PUSTAKA}

1. Eeden $M$ Van, Heugten CM Van, Evers SMAA. The economic impact of stroke in The Netherlands: the (sic) restore4stroke study. BMC Public Health [Internet]. BioMed Central Ltd; 2012;12(1):122. Available from: http://www. biomedcentral. com/14712458/12/122

2. Essue BM, Hackett $M L$, Li $Q$, Glozier N, Lindley R, Jan S. How Are Household Economic Circumstances Affected After a Stroke? The Psychosocial Outcomes In Stroke ( POISE) Study. 2012;

3. CMSA. Standards of Practice for Case Management [Internet]. Little Rock AR USA: Case Management Society of America; 2010. Available from: www. acmaweb.org

4. ACMA. Standards of Practice \& Scope of Services [Internet]. Little Rock AR USA: American Case Management Association; 2013. Available from: www. acmaweb.org

5. McDonald $K$, Sundaram $V$, Bravata D, et al. Care Coordination eds. Closing the quality gap: a critical analysis of quality improvement strategies. Technical Review. AHRQ Publication No. 04(07)-0051-7; 2007.

6. Mayo NE, Scott S. Evaluating a complex intervention with a single outcome may not be a good idea: an example from a randomised trial of stroke case management. age ageing-oxford J. 2011;71824.

7. Carroll $C$, Patterson $M$, Wood $S$, Booth A, Rick J, Balain S. A conceptual framework for implementation fidelity. Implement Sci. 2007;2(40):1-9.

8. Hasson H. Systematic evaluation of implementation fidelity of complex interventions in health and social care. Implement Sci. 2010;5(67): 1-9.

9. Komisi Akreditasi Rumah Sakit. Panduan Pelaksanaan Dokter Penanggung Jawab Pelayanan (DPJP) dan Case Manager. 1st ed. Jakarta: Komisi Akreditasi Rumah Sakit; 2015. 30-36 p.

10. Hasson H, Blomberg S, Dunér A. Fidelity and moderating factors in complex interventions: a case study of a continuum of care program for frail elderly people in health and social care. Implement Sci [Internet]. 2012;7:23:1-11. Available from: http://www. implementationscience.com/conte nt/7/1/23

11. Mullahy CM. The Case Manager's Handbook. 6th ed. Martin A, editor. Burlington: jones \& bartlett learning; 2016. 51 p.

12. Badan Penelitian dan Pengembangan Kesehatan Kementerian Kesehatan RI. Riset Kesehatan Dasar. Jakarta: Kementerian Kesehatan RI; 2013.

13. Departemen Kesehatan RI. Buku Petunjuk Pengisian, Pengolahan, dan Penyajian Data Rumah Sakit. Jakarta: Departemen Kesehatan RI; 2005.

14. Ouwens $M$, Wollersheim $H U B$, Hermens $R$, Hulscher $M$. Integrated care programmes for chronically ill patients : a review of systematic reviews. Int $J$ Qual Heal care. 2005;17(2):141-6.

15. Ozcelik H, Fadiloglu C, Karabulut $B$, Uyar M. Examining the Effect of the Case Management Model on Patient Results in the Palliative 
Care of Patients With Cancer. Am $\mathrm{J}$ Hosp Palliat Med. 2014;31(6):655-64.

16. Norris SL, Nichols PJ, Caspersen $\mathrm{CJ}$, et al. The effectiveness of disease and case management for people with diabetes. Am J Prev Med. 2002;22(4S).

17. Wulff CN, Thygesen M, Søndergaard J, Vedsted P. Case management used to optimize cancer care pathways: a systematic review. BMC Health Serv Res [Internet]. 2008 Jan [cited 2016 Apr 11];8:227. Available from: http://www. pubmedcentral.nih.gov/articlere nder.fcgi?artid $=2596122 \&$ tool $=p$ mcentrez\&rendertype $=$ abstract

18. Wulff CN. The Effect of HospitalBased Case Management in Cancer Care Pathways. aarhus university; 2012.

19. Damschroder LJ, Aron DC, Keith RE, Kirsh SR, Alexander JA, Lowery JC. Fostering implementation of health services research findings into practice: a consolidated framework for advancing implementation science. 2009;15:1-15. 